\title{
IMPLEMENTATION OF INQUIRY LEARNING MODEL TO IMPROVE MATHEMATICAL LEARNING OUTCOMES OF STUDENTS IN CLASS VIIIA SMPN 4 TAMBANG
}

\section{PENERAPAN MODEL PEMBELAJARAN INQUIRY UNTUK MENINGKATKAN HASIL BELAJAR MATEMATIKA PESERTA DIDIK KELAS VIII ${ }_{A}$ SMPN 4 TAMBANG}

\author{
Ratna Syari, Titi Solfitri, Armis \\ Pendidikan Matematika, Universitas Riau \\ Email : ratna.syari@student.unri.ac.id
}

Submitted: (23 April 2020); Accepted: (26 Mei 2020);

Published: (31 Mei 2020)

\begin{abstract}
This research aims to improve learning process and students' mathematics learning achievement by applying Inquiry Learning model. Subject of this research are students of VIII $I_{A} S M P N 4$ Tambang in second semester of academic year 2018/2019 which consist of 29 students. This research is a classroom action research with 2 cycles. The instruments of this research are learning Instrument (Syllabus, Lesson Plans, and Activity Sheets) and data collecting instruments (observation Sheets for teacher and students) and Students' Mathematic tests. The data collecting techniques in this research are observation techniques and test techniques. The observation sheets were analyzed in qualitative descriptive, while the students mathematic tests were analyzed in quantitative descriptive. Qualitative descriptive analysis results show an improvement of learning process after the implementation of the action (first and second cycle). Quantitative descriptive analysis shows the improvement in students' mathematic scores. The number of students in the "very high" and "high" interval increases. While the number of students in the "very low", "low", and "medium" interval decreases. Based on the result of this research, it can be concluded that the implementation of Inquiry Learning model can be improves the learning process and the students' mathematics learning achievement in class of VIII $S M P N 4$ Tambang.
\end{abstract}

Keywords : Learning process, Mathematical learning outcomes, Inquiry Learning Model, Classroom action research

\section{PENDAHULUAN}

Ilmu matematika menekankan pada pentingnya kemampuan berpikir logis, kritis, analitis, kreatif, sistematis, serta kemampuan bekerjasama, membantu menyelesaikan permasalahan dalam kehidupan sehari-hari dan berkaitan dalam mengembangkan disiplin ilmu lainnya. Hal ini sejalan dengan pendapat Sarama (Siregar, 2017) yang menyatakan bahwa manfaat ilmu matematika dapat dirasakan dalam kehidupan manusia, di berbagai bidang pekerjaan, serta dapat pula membentuk sikap dan pola pikir manusia. Pentingnya pembelajaran matematika ini dapat dilihat dari tujuan pembelajaran matematika yang terdapat pada Permendikbud nomor 58 tahun 2014 yakni untuk menumbuhkan kemampuan hidup.
Kemampuan yang dapat ditumbuhkan melalui pembelajaran matematika sebagaimana dalam Permendikbud nomor 58 tentang Pedoman Mata Pelajaran Matematika dan Permendikbud nomor 21 tentang standar isi diantaranya adalah (1) menggunakan kemampuan berpikir dan bernalar dalam pemecahan masalah, (2) menyampaikan gagasan secara efektif, (3) mempunyai sikap dan perilaku yang sesuai dengan nilai-nilai matematika dan pembelajarannya, seperti konsisten, menjunjung tinggi kesepakatan, meghargai perbedaan pendapat, teliti, kreatif dan terbuka. Tampak bahwa tujuan pembelajaran matematika secara umum berfokus pada pengembangan kemampuan berpikir, penumbuhan karakter dan perilaku positif. 
Ketercapaian tujuan pembelajaran matematika ditandai dengan keberhasilan peserta didik dalam mencapai kompetensi dasar yang ditetapkan dengan melihat hasil belajar matematika peserta didik. Proses yang dilakukan untuk mengukur pencapaian kompetensi dasar peserta didik secara berkelanjutan dan melihat kemajuan serta perbaikan hasil belajar peserta didik dilakukan melalui ulangan. Ulangan merupakan proses yang dilakukan secara berkelanjutan untuk mengukur pencapaian kompetensi peserta didik serta mengetahui kemajuan dan perbaikan hasil belajar peserta didik (Kemendikbud, 2016).

Menurut Sanjaya (2013) Hasil belajar peserta didik merupakan parameter untuk mengetahui tingkat keberhasilan peserta didik dalam memahami materi pelajaran dari proses belajarnya. Hasil belajar matematika yang diharapkan adalah hasil belajar matematika peserta didik termasuk dalam kategori tinggi. Agar hasil belajar matematika peserta didik tinggi, maka proses pembelajaran harus aktif dan mampu mengkonstruksi pengetahuan peserta didik dalam belajar. Untuk mencapai hal tersebut, pemerintah sudah menerapkan kurikulum 2013, dimana kegiatan proses pembelajaran yang dilakukan berpusat pada peserta didik bukan pada guru agar pembelajaran menjadi bermakna. Hal ini dinyatakan dalam permendikbud no 22 tentang proses pembelajaran. Namun, berdasarkan fakta dilapangan, hasil belajar matematika peserta didik masih tergolong rendah. Hal ini didasarkan pada data nilai ulangan peserta didik kelas VIII $_{\mathrm{A}}$ SMPN 4 Tambang pada materi sudut pusat dan sudut keliling semester genap tahun ajaran 2018/2019. Dari data tersebut terlihat bahwa hanya 13 dari 29 orang peserta didik dikelas VIII $_{\mathrm{A}}$ yang mencapai ketuntasan belajar minimal yang ditetapkan. Untuk mengetahui penyebab hasil belajar matematika peserta didik rendah, peneliti melakukan observasi dan wawancara ke sekolah.

Berdasarkan hasil wawancara dengan guru matematika kelas VIII $_{\mathrm{A}}$ SMPN 4 Tambang, peneliti memperoleh informasi tentang proses pembelajaran di dalam kelas antara lain: (1) peserta didik kurang menguasai konsep pembelajaran dengan baik; (2) kurangnya interaksi antar peserta didik dan peserta didik dengan guru; (3) peserta didik tidak terampil dan kreatif dalam menggunakan media pembelajaran; (4) Kurangnya percaya diri peserta didik dalam menjawab soal atau pertanyaan guru; (5) daya ingat peserta didik dengan pelajaran sebelumnya masih rendah atau peserta didik mudah lupa jika ditanya kembali pelajaran sebelumnya.

Selanjutnya peneliti melakukan observasi terhadap kegiatan belajar mengajar guru di dalam kelas untuk mengetahui proses pembelajaran di kelas VIII SMPN S Tambang. Berdasarkan kegiatan observasi ini, proses pembelajaran pada kegiatan inti belum sesuai dengan proses pembelajaran yang sudah ditetapkan pemerintah, yaitu kurikulum 2013. Berdasarkan Permendikbud No. 22 tahun 2016 tentang Standar Proses untuk Satuan Pendidikan Dasar dan Menengah, pelaksanaan kegiatan inti untuk mencapai Kompetensi Dasar (KD) dilakukan secara interaktif, inspiratif, menyenangkan dan memotivasi peserta didik untuk berpartisipasi aktif. Dari kegiatan pengamatan, terlihat peserta didik hanya memperoleh informasi pembelajaran seluruhnya dari guru, tidak ada keterlibatan peserta didik dalam menemukan konsep pembelajaran. Sehingga peserta didik terlihat tidak aktif dalam kegiatan pembelajaran, yang bertentangan dengan kegiatan pembelajaran yang diinginkan kurikulum 2013.

Selanjutnya peneliti melakukan wawancara dengan peserta didik. Berdasarkan hasil wawancara terkait proses pembelajaran dan respon dikelas dari peserta didik, peneliti memperoleh informasi antara lain: (1) peserta didik mudah lupa dengan pelajaran sebelumnya karena kurang memahami konsep pembelajaran, hal ini yang menyebabkan hanya sedikit peserta didik yang merespon pertanyaan guru; (2) peserta didik kurang percaya diri untuk menyampaikan gagasannya dalam menjawab pertanyaan yang diberikan guru; (3) proses pembelajaran yang dilakukan setiap pertemuan sama, misalnya tidak ada variasi penggunaan media pembelajaran yang bisa digunakan peserta didik dalam menemukan konsep materi yang dipelajari; (4) peserta didik tidak dapat mengerjakan soal latihan yang berbeda dengan contoh soal yang diberikan guru, hal ini dikarenakan kurangnya 
kemampuan berpikir peserta didik dalam menalarkan jawaban, dan (5) jika dilakukan pembelajaran secara berkelompok peserta didik yang pintar mengeluh karena dia mencari jawabannya sediri, sedangkan temannya yang lain hanya menyalin jawabannya.

Berdasarkan hasil observasi dan wawancara peneliti menyimpulkan penyebab permasalahan yang terjadi di dalam kelas pada mata pelajaran matematika yaitu : (1) kurangnya keterlibatan peserta didik untuk aktif dalam mengkonstruksi pengetahuannya; (2) tidak terlibat aktif untuk menemukan dan mencari tahu tentang materi yang dipelajari dari sumber belajar; (3) menjadikan guru sebagai satu-satunya sumber belajar; (4) kadang-kadang peserta didik tidak ingat atau mudah lupa dengan materi yang sudah diajarkan. Dari permasalahan tersebut, peserta didik menjadi kurang memahami konsep pembelajaran dengan baik dan timbulnya kurang percaya diri peserta didik dalam menyampaikan gagasannya untuk merespon pertanyaan guru. Hal ini menyebabkan proses pembelajaran yang dilakukan terlihat menjadi tidak aktif, dan guru menjadi sumber belajar utama bagi peserta didik.

Berdasarkan permasalahan yang sudah dipaparkan, peneliti ingin menerapkan model pembelajaran yang dapat mengkonstruksikan pengetahuan peserta didik untuk merangsang peserta didik berpikir kritis sehingga meningkatkan percaya diri serta menekankan kegiatan pembelajaran pada aktivitas peserta didik untuk mencari informasi yang dibutuhkan dari aneka sumber belajar dan menemukan jawaban sendiri dari masalahnya. Dengan menerapkan model pembelajaran ini diharapkan peserta didik belajar dari informasi yang dia peroleh dalam menemukan jawabannya sendiri, untuk meningkatkan daya ingat peserta didik terhadap pembelajarannya. Selain itu, dapat menumbuhkan kreativitas peserta didik baik secara individu maupun kelompok dalam bekerja, sehingga terjalin interaksi antar peserta didik dan peserta didik dengan guru. Salah satu model pembelajaran yang dapat diterapkan yaitu model pembelajaran Inquiry. Hal ini dikarenakan dalam penggunaan model pembelajaran Inquiry terdapat langkah mengajukan hipotesis dan menguji hipotesis. Pada langkah ini, peserta didik diberikan pertanyaan dari suatu permasalahan yang mengarahkan peserta didik untuk memberikan jawabannya, kemudian peserta didik akan menentukan jawaban yang dapat diterima berdasarkan pada data-data yang diperolehnya saat pengumpulan data, sehingga peserta didik dapat menyakini kebenaran jawabannya dari hasil proses menemukan tersebut.

Menurut Nurdyansyah (2016), model pembelajaran inkuiri merupakan model pembelajaran yang meningkatkan kemandirian peserta didik dalam menemukan pengetahuan atau pemahaman atas pemecahan suatu masalah yang dikaitkan dengan masalah nyata dalam kehidupan peserta didik, berdasarkan data-data yang nyata hasil dari observasi atau pengamatannya. Peserta didik harus memproses informasi yang diperolehnya untuk memahami makna dan secara aktif terlibat dalam pembelajaran. Selain itu model pembelajaran Inquiry bertujuan untuk memberdayakan peserta didik dalam membangun pengetahuannya dan menemukan jawaban, sedangkan guru hanya sebagai fasilitator dan motivator peserta didik dalam belajar. Sehingga peserta didik tidak mudah melupakan konsep yang diperoleh dari hasil pembelajarannya sendiri, kemudian menjadikan percaya diri peserta didik meningkat.

Menurut Sanjaya (2015) dan Trianto (2014) model pembelajaran Inquiry memiliki keunggulan anatara lain: : (1) peserta didik dominan dalam proses pembelajaran untuk mencari dan menemukan sendiri pemecahan masalah; (2) Meningkatkan kemandirian peserta didik dalam proses pembelajaran untuk mencari dan menemukan jawaban, sehingga menumbuhkan sikap percaya diri; (3) mengembangkan kemampuan berpikir secara sistematis, logis dan kritis, atau pengembangan kemampuan intelektual sebagai bagian dari proses mental; (4) sistem pembelajaran yang merata terhadap seluruh peserta didik, baik yang berkemampuan tinggi, sedang, maupun rendah; (5) menumbuhkan kemampuan kreativitas peserta didik, baik secara individual atau kelompok.

Berdasarkan uraian tersebut, maka peneliti akan menerapkan model pembelajaran 
Inquiry untuk memperbaiki proses belajar dan meningkatkan hasil belajar matematika peserta didik kelas VIIIA SMPN 4 Tambang. Dalam penelitian ini peneliti akan menerapkan model pembelajaran Inquiry pada KD 3.9 yaitu materi membedakan dan menentukan luas permukaan dan volume bangun ruang sisi datar (kubus, balok, prisma, dan limas) dan KD 4.9 yaitu menyelesaikan masalah yang berkaitan dengan luas permukaan dan volume bangun ruang sisi datar (kubus, balok, prisma, dan limas).

\section{METODE}

Bentuk penelitian ini adalah Penelitian Tindakan Kelas (PTK). Arikunto, Suhardjono, \& Supardi (2015) menyatakan bahwa penelitian tindakan kelas merupakan suatu pencermatan terhadap kegiatan yang sengaja dilakukan di dalam kelas. Peneliti dan guru berkerjasama dalam proses pelaksanaan tindakan. Pelaksanaan penelitian ini mengikuti tahaptahap penelitian tindakan kelas yang pelaksanaannya terdiri dari dua siklus Pada siklus pertama dimulai dari pertemuan pertama sampai pertemuan ketiga, pada pertemuan keempat dilakukan penilaian harian I. Siklus kedua dilakukan dari pertemuan kelima sampai pertemuan ketujuh, sedangkan pertemuan kedelapan dilakukan penilaian harian II. Menurut Arikunto, Suhardjono, \& Supardi (2015), penelitian tindakan kelas dilaksanakan melalui empat tahap, anatara lain:

\section{Perencanaan (Planning)}

Pada tahapan ini peneliti: (1) Menyusun Rencana Pembelajaran (RPP), lembar kerja peserta didik (LKPD) yang disesuaikan dengan model pembelajaran inquiry dan materi/bahan ajar; (2) Membuat lembar pengamatan aktivitas guru, pengamatan aktivitas peserta didik dan soal penilaian harian I dan II; (3) Peneliti berdiskusi dengan guru matematika terkait prosedur yang akan diterapkan peneliti di dalam kelas.

\section{Pelaksanaan;}

Pada tahap ini peneliti akan melaksanakan semua rencana yang telah dibuat ke dalam kelas. Peneliti bertindak sebagai guru dan melaksanakan proses pembelajaran dengan menggunakan model pembelajaran inquiry.

3. Pengamatan
Kegiatan pengamatan dilakukan bersamaan dengan pelaksanaan tindakan. Pengamatan ini dilakukan oleh guru matematika kelas VIIIA SMPN 4 Tambang dan seorang mahasiswa pendidikan matematika. Guru kelas VIIIA akan mengamati aktivitas peneliti sebagai guru pada saat proses belajar mengajar berlangsung, sedangkan mahasiswa pendidikan matematika akan mengamati aktivitas peserta didik selama proses pembelajaran.

4. Refleksi.

Pada tahap ini peneliti dan pengamat akan membahas hasil pengamatan pelaksanaan pembelajaran pada setiap pertemuan. Hal ini bertujuan untuk mengevaluasi proses pembelajaran yang sudah peneliti lakukan, sebagai dasar perbaikan pada perencanaan tindakan berikutnya.

Subjek penelitian pada penelitian ini adalah peserta didik kelas VIIIA SMPN 4 Tambang pada semester genap tahun pelajaran 2018/2019, yaitu sebanyak 29 orang peserta didik, yang terdiri dari 13 peserta didik laki-laki dan 16 peserta didik perempuan dengan tingkat kemampuan akademis yang heterogen. Pada materi pokok bangun ruang sisi datar. Data penelitian ini terdiri dari data hasil pengamatan dan data hasil belajar matematika. Sedangkan instrumen penelitian yang digunakan adalah perangkat pembelajaran yang terdiri dari Silabus, Rencana Pelaksanaan Pembelajaran (RPP), dan Lembar Kerja Peserta Didik (LKPD). Instrumen pengumpul data penelitian terdiri dari lembar pengamatan aktivitas guru dan peserta didik dan tes hasil belajar matematika yang diperoleh dari penilaian harian I dan penilaian harian II.

Teknik pengumpulan data penelitian ini berupa teknik pengamatan dan teknik tes tertulis. Data penelitian hasil observasi dianalisis dengan teknik analisis deskriptif kualitatif sedangkan data yang diperoleh dari tes tertulis dianalisis dengan teknik analisis deskriptif kuantitatif. Adapun analisis data pada penelitian ini adalah sebagai berikut.

\section{Analisis Data Kulitatif}

Analisis data hasil pengamatan aktivitas guru dan peserta didik didasarkan pada hasil lembar pengamatan aktivitas guru dan peserta didik. Hal ini bertujuan untuk melihat aktivitas 
guru dan peserta didik dalam proses pembelajaran matematika di kelas VIIIA SMPN 4 Tambang dan untuk melihat keoptimalan dari aktivitas guru dan peserta didik yang sudah dilakukan. Data hasil pengamatan aktivitas guru dan peserta didik merupakan data kualitatif yang akan dianalisis secara deskriptif kualitatif. Muslich (2012) menyatakan bahwa tahapan dalam analisis data kualitatif terdiri dari tiga tahap, yaitu reduksi data, paparan data, dan penarikan kesimpulan.

2. Analisis Data Kuantitatif

Analisis data tentang hasil belajar matematika peserta didik dilakukan dengan melihat hasil belajar peserta didik secara individu pada KD 3.9 membedakan dan menentukan luas permukaan dan volume bangun ruang sisi datar dan KD 4.9 menyelesaikan masalah yang berkaitan dengan bangun ruang sisi datar. Analisis data hasil belajar matematika peserta didik kelas VIIIA SMPN 4 Tambang akan dianalisis secara deskriptif kuantitatif dengan menggunakan tabel distribusi frekuensi.

Data hasil belajar peserta didik disajikan ke dalam tabel distribusi frekuensi untuk melihat peningkatan hasil belajar matematika peserta didik. Tabel distribusi frekuensi dari data hasil belajar matematika peserta didik sebelum dan sesudah tindakan disajikan dalam bentuk tabel distribusi frekuensi agar diperoleh gambaran yang ringkas dan jelas mengenai hasil belajar matematika peserta didik, serta dapat melihat apakah terjadi peningkatan atau penurunan hasil belajar matematika peserta didik sebelum dan sesudah tindakan.

Menurut Arikunto \& Jabar (2010) kriteria kuantitatif tanpa pertimbangan ini dibuat dengan menggunkan rentang bilangan tanpa memperhitungkan apa-apa, dilakukan dengan membagi rentang bilangan menjadi 5 yaitu tinggi sekali, tinggi, cukup, rendah dan rendah sekali. Jika frekuensi peserta didik yang bernilai rendah sekali, rendah dan cukup menurun jumlahnya dari sebelum dilakukan tindakan ke setelah dilakukan tindakan atau jika frekuensi peserta didik yang bernilai tinggi dan tinggi sekali meningkat jumlahnya dari sebelum dilakukan tindakan ke setelah dilakukan tindakan maka terjadi peningkatan hasil belajar matematika peserta didik.
Jika keadaan setelah dilakuka tindakan lebih baik, maka dapat dikatakan bahwa tindakan yang diberikan berhasil, akan tetapi jika tidak ada bedanya atau bahkan lebih buruk, maka tindakan belum berhasil. Keadaan lebih baik yang dimaksudkan pada penelitian ini adalah jika terjadi perbaikan proses dan hasil belajar matematika peserta didik setelah diterapkan model pembelajaran Inquiry. Kriteria keberhasilan tindakan dalam penelitian ini adalah sebagai berikut.

\section{Terjadinya Perbaikan Proses Belajar \\ Perbaikan proses pembelajaran} dilakukan berdasarkan hasil refleksi terhadap proses pembelajaran, yang diperoleh melalui lembar pengamatan aktivitas guru dan peserta didik. Perbaikan proses pembelajaran terjadi jika aktivitas guru dan peserta didik semakin membaik dan kelemahan semakin sedikit. Selain itu, perbaikan proses pembelajaran juga terjadi jika proses pembelajaran telah terlaksana optimal, semakin baik, aktif dan interaktif dari sebelum dilakukan tindakan ke setelah dilakukan tindakan sesuai dengan penerapan model pembelajaran Inquiry.

2. Peningkatan Hasil Belajar Matematika

Peningkatan hasil belajar matematika peserta didik dapat dilihat dari analisis distribusi frekuensi. Apabila terjadi perubahan frekuensi peserta didik pada setiap interval nilai rendah sekali, rendah dan cukup ke interval nilai yang lebih tinggi dan tinggi sekali (ke arah yang lebih baik) dari nilai dasar (sebelum pelaksanaan tindakan) ke penilaian harian I (setelah pelaksanaan tindakan) dan dari penilaian harian I ke penilaian harian II (setelah pelaksanaan tindakan), maka dapat dikatakan bahwa hasil belajar matematika peserta didik meningkat.

\section{HASIL DAN PEMBAHASAN}

Pelaksanaan proses pembelajaran dengan menerapkan Model Pembelajaran Inquiry memberikan pengalaman belajar kepada peserta didik dalam memahami konsep materi pelajaran berdasarkan kegiatan menemukan dalam proses belajarnya, aktif dalam berdiskusi kelompok, berani menyampaikan pendapat, serta aktif dalam menanggapi presentasi hasil diskusi kelompok. Sehingga pembelajaran menjadi bermakna, sebagaimana proses pembelajaran 
yang diharapkan dari kurikulum 2013. Berdasarkan RPP yang telah dipersiapkan dengan alokasi waktu 80 menit dan 120 menit, kegiatan pembelajaran lebih dominan dilakukan oleh peserta didik. Hal ini terlihat dari Rencana Pelaksanaan Pembelajaran (RPP) pada langkahlangkah kegiatan inti dan penutup lebih banyak berpusat pada peserta didik dibandingkan guru.

Berdasarkan analisis lembar pengamatan aktivitas guru dan peserta didik dari siklus I ke siklus II terjadi perbaikan proses pembelajaran. Dari hasil pengamatan terlihat aktivitas guru dan peserta didik saat peneliti memberikan apersepsi, motivasi dan penyampaian tujuan pembelajaran pada siklus II lebih baik dan interaktif daripada siklus I. Dalam hal ini peneliti selalu memotivasi dan berusaha mengajak peserta didik untuk berani memberikan jawabannya dan aktif untuk bertanya. Selanjutnya pada kegiatan menyampaikan langkah-langkah pembelajaran dan membagikan LKPD pada setiap pertemuan, ada peserta didik yang kurang memperhatikan saat peneliti menyampaikan langkah-langkah pembelajaran, kemudian peneliti memberikan teguran dan pemahaman pentingnya penyampaian guru.

Selanjutnya pada kegiatan orientasi, kesadaran dan fokus peserta didik membaca orientasi masalah semakin baik pada setiap pertemuan. Dalam hal ini guru menarik perhatian peserta didik dengan memberikan pemahaman pentingnya membaca dan memahami orientasi masalah agar mudah dalam menjawab masalah di LKPD dan saat mengerjakan LKPD.

Berikutnya pada kegiatan merumuskan masalah dan merumuskan hipotesis, kemampuan berpikir peserta didik dalam memberikan jawaban sementara semakin baik. dan mampu menguji jawabannya menjadi jawaban yang dapat diterima berdasarkan kegiatan mengumpulkan data yang diperolehnya pada pengerjaan LKPD.

Selanjutnya pada kegiatan menyajikan hasil diskusi kelompok, keberanian peserta didik dalam mempresentasikan hasil kerja kelompoknya ke depan kelas semakin baik dan meningkat di siklus ke II, serta peserta didik juga berani merespon atau memberi tanggapan terhadap kelompok penyaji. Kemudian pada kegiatan memberikan kesimpulan, peserta didik sudah mengerti bagaimana membuat kesimpulan pembelajaran dan aktif serta berani menyampaikan kesimpulannya.

Dilihat dari proses pembelajaran pada kegiatan inti dan akhir peserta didik lebih aktif dalam kegiatan pembelajaran dibandingkan guru. Pada kegiatan inti guru hanya sebagai fasilitator dan motivator untuk memberikan arahan mengerjakan LKPD, selebihnya peserta didik yang aktif dalam proses pembelajaran. Pada kegiatan akhir peserta didik juga lebih aktif, guru hanya membutuhkan waktu kurang lebih 5 menit untuk menyampaikan materi yang akan dipelajari dan menutup pelajaran dengan mengucapkan salam.

Selanjutnya ditinjau dari hasil belajar matematika, peningkatan hasil belajar dilihat dari analisis distribusi frekuensi nilai pengetahuan dan keterampilan peserta didik. Berikut ini distribusi frekuensi dari nilai hasil belajar matematika peserta didik kompetensi pengetahuan pada Skor Dasar, Skor Penilaian Harian I dan Skor Penilaian Harian II disajikan dalam tabel 1 .

Tabel 1. Tabel Distribusi Frekuensi Hasil Belajar Matematika Peserta Didik Pada Kompetensi Pengetahuan

\begin{tabular}{ccccc}
\hline & \multicolumn{4}{c}{ Frekuensi Peserta Didik } \\
\cline { 2 - 5 } $\begin{array}{c}\text { Inter val } \\
\text { Nilai }\end{array}$ & $\begin{array}{c}\text { Skor } \\
\text { Dasar }\end{array}$ & $\begin{array}{c}\text { Skor } \\
\text { Penilaian } \\
\text { Harian I }\end{array}$ & $\begin{array}{c}\text { Skor } \\
\text { Penilaian } \\
\text { Harian II }\end{array}$ & $\begin{array}{c}\text { Kategori } \\
\text { Nilai }\end{array}$ \\
\hline $81-100$ & 5 & 12 & 15 & $\begin{array}{c}\text { Tinggi } \\
\text { Sekali }\end{array}$ \\
$61-80$ & 9 & 10 & 13 & $\begin{array}{c}\text { Tinggi } \\
\text { Cukup } \\
41-60\end{array}$ \\
$21-40$ & 3 & 7 & 1 & $\begin{array}{c}\text { Rendah } \\
\text { Rendah } \\
0-20\end{array}$ \\
\hline & 1 & 0 & 0 & Sekali \\
\hline
\end{tabular}

Berdasarkan Tabel 1 dapat dilihat bahwa terjadi penurunan frekuensi peserta didik yang berada pada kategori nilai rendah sekali, rendah dan cukup. Pada skor dasar banyak peserta didik yang berada pada kategori rendah sekali, rendah dan cukup sebanyak 15 orang, kemudian setelah dilaksanakan penilaian harian I menurun jumlahnya menjadi 7 orang, dan 1 orang setelah dilaksakan penilaian harian II. Selanjutnya pada kategori nilai tinggi dan tinggi sekali sebanyak 14 orang pada skor dasar, meningkat 22 orang pada skor penilaian harian 
I dan meningkat lagi pada skor penilaian harian II sebanyak 28 orang peserta didik. Hal ini menunjukkan bahwa peserta didik yang berada pada kategori rendah sekali, rendah dan cukup frekuensinya mengalami penurunan dan meningkat pada kategori nilai tinggi dan tinggi sekali. Penjelasan data di atas menunjukkan bahwa setelah pelaksanaan tindakan terjadi peningkatan hasil belajar matematika peserta didik pada kompetensi pengetahuan yang ditandai dengan peningkatan frekuensi peserta didik ke interval nilai tinggi dan tinggi sekali (ke arah yang lebih baik), dari frekuensi peserta didik yang kategori nilai rendah sekali, rendah dan cukup berkurang dari sebelum dilakukan tindakan ke setelah dilakukan tindakan.

Selanjutnya distribusi frekuensi dari hasil belajar matematika peserta didik kompetensi keterampilan pada penilaian harian I dan penilaian harian II disajikan pada tabel 2 berikut ini.

Tabel 2. Tabel Distribusi Frekuensi Hasil Belajar Matematika Peserta Didik Pada Kompetensi Keterampilan

\begin{tabular}{|c|c|c|c|}
\hline \multirow[b]{2}{*}{$\begin{array}{c}\text { Interval } \\
\text { Nilai }\end{array}$} & \multicolumn{3}{|c|}{ Frekuensi Peserta Didik } \\
\hline & $\begin{array}{c}\text { Skor } \\
\text { Penilaian } \\
\text { Harian I }\end{array}$ & $\begin{array}{c}\text { Skor } \\
\text { Penilaian } \\
\text { Harian II }\end{array}$ & $\begin{array}{c}\text { Kategori } \\
\text { Nilai }\end{array}$ \\
\hline $81-100$ & 0 & 4 & $\begin{array}{l}\text { Tinggi } \\
\text { Sekali }\end{array}$ \\
\hline $\begin{array}{l}61-80 \\
41-60\end{array}$ & $\begin{array}{l}14 \\
11\end{array}$ & $\begin{array}{c}15 \\
8\end{array}$ & $\begin{array}{l}\text { Tinggi } \\
\text { Cukup }\end{array}$ \\
\hline $21-40$ & 4 & 2 & Rendah \\
\hline $0-20$ & 0 & 0 & $\begin{array}{c}\text { Rendah } \\
\text { Sekali }\end{array}$ \\
\hline
\end{tabular}

Berdasarkan Tabel 2 dapat dilihat bahwa terjadi penurunan frekuensi peserta didik pada interval nilai rendah dan cukup dari skor penilaian harian I ke skor penilaian harian II. Ada 15 peserta didik yang nilainya tersebar di kategori nilai rendah sekali, rendah dan cukup pada penilaian harian I, kemudian mengalami perubahan pada penilaian harian II menjadi 10 peserta didik. Selanjutnya peserta didik yang berada pada kategori nilai tinggi dan tinggi sekali pada penilaian I sebanyak 14 orang kemudian meningkat menjadi sebanyak 19 orang pada penilaian harian II.
Penjelasan data di atas menunjukkan bahwa setelah pelaksanaan tindakan terjadi peningkatan hasil belajar matematika peserta didik pada kompetensi keterampilan. Hal ini dapat dilihat dari perubahan frekuensi peserta didik pada kategori nilai rendah sekali, rendah dan cukup mengalami penurunan jumlah dari penilaian harian I ke penilaian harian II, atau pada kategori nilai tinggi dan tinggi sekali mengalami peningkatan jumlah peserta didik.

Dari keseluruhan uraian yang telah dikemukakan dapat disimpulkan bahwa hipotesis tindakan yang diajukan dapat diterima kebenarannya. Dengan kata lain penerapan model pembelajaran Inquiry dapat memperbaiki proses pembelajaran dan meningkatkan hasil belajar matematika peserta didik kelas $\mathrm{VIII}_{\mathrm{A}}$ SMPN 4 Tambang pada materi pokok bangun ruang sisi datar semester genap tahun ajaran 2018/2019. Hal yang sama juga diungkapkan oleh Israwani (2015) yang mengatakan bahwa bahwa Pembelajarn dengan Inquiry Learning model dapat meningkatkan hasil belajar yang signifikan, dengan kualifikasi: (1) Hasil belajar peserta didik mengalami peningkatan yang signifikan dari nilai rata-rata kelas sebesar 66,74, menjadi sebesar 72,96 pada siklus I dan siklus II menjadi 83; (2) Aktivitas peserta didik juga mengalami peningkatan dari siklus I sampai ke siklus II; (3) motivasi belajar peserta didik berpengaruh positif terhadap kemampaun keruangan peserta didik. Hasil ini juga didukung oleh Iswatun, Mosik, \& Subali (2017) yang mengatakan bahwa peningkatan hasil belajar kognitif kelas eksperimen sebesar 0,53 lebih tinggi daripada kelas kontrol sebesar 0,38 melalui penerapan model pembelajaran inkuiri terbimbing.

\section{SIMPULAN}

Berdasarkan hasil penelitian dan pembahasan, dapat disimpulkan bahwa penerapan model Pembelajaran Inquiry dapat memperbaiki proses pembelajaran dan meningkatkan hasil belajar matematika peserta didik kelas VIIIA SMPN 4 Tambang semester genap tahun pelajaran 2018/2019 pada materi pokok bangun ruang sisi datar. 
Volume 2, Nomor 2, Mei 2020

DOI: https://doi.org/10.33578/prinsip.v2i2.44

jprinsip.ejournal.unri.ac.id

\section{REKOMENDASI}

Berdasarkan pembahasan dan simpulan dari penelitian ini, peneliti mengajukan beberapa rekomendasi dalam penerapan model pembelajaran Inquiry, diantaranya:

1. Model Pembelajaran Inquiry dapat dijadikan sebagai salah satu alternatif model pembelajaran yang dapat melibatkan peserta didik secara aktif dan mampu meningkatkan hasil belajar.

2. Bagi guru atau peneliti yang ingin menerapkan model pembelajaran Inquiry harus dapat memotivasi, memonitor dan mengarahkan peserta didik dengan baik selama proses pembelajaran.

3. Dalam menerapkan pembelajaran dengan model pembelajaran Inquiry, sebaiknya guru menyiapkan Lembar Kerja Peserta Didik (LKPD), sehingga dapat mengarahkan peserta didik dalam mengumpulkan informasi dan mengolah informasi secara mandiri.

\section{DAFTAR PUSTAKA}

Arikunto, S., \& Jabar, C.S.A. (2010). Evaluasi program pendidikan. Bumi Aksara

Arikunto, S., Suhardjono, \& Supardi. (2015). Penelitian tindakan kelas. Bumi Aksara

Israwani. (2015). Penggunaan model pembelajaran inkuiri pada materi operasi hitung bilangan di kelas I SD Negeri 53 Banda Aceh. Jurnal Peluang, 3(2), 55 - 64

Iswatun, I., Mosik, M., \& Subali, B. (2017). Penerapan model pembelajaran inkuiri terbimbing untuk meningkatkan KPS dan hasil belajar siswa SMP kelas VIII. Jurnal Inovasi Pendidikan, 3(2), $150-160$. https://doi.org/10.21831/jipi.v3i2.14871
Kemendikbud. (2014). Salinan Lampiran Permendikbud No. 58 Tahun 2014 Tentang Kurikulum 2013 Sekolah Menengah Pertama/Madrasah Tsanawiyah. Kemendikbud

Kemendikbud. (2016). Salinan Lampiran Permendikbud No. 21 Tentang Standar Isi Pendidikan Dasar dan Menengah. Kemendikbud

Kemendikbud. (2016). Salinan Lampiran Permendikbud No. 22 Tentang Standar Proses Pendidikan Dasar dan Menengah. Kemendikbud

Kemendikbud. (2016). Salinan Lampiran Permendikbud No. 23 Tentang Standar Penilaian Pendidikan. Kemendikbud

Muslich, M. (2012). Melaksanakan PTK itu mudah. Bumi Aksara.

Nurdyansyah. (2016). Inovasi model pembelajaran sesuai kurikulum 2013. Nizamia Learning Center.

Sanjaya, W. (2013). Strategi pembelajaran berorientasi standar proses pendidikan. Kencana Prenada Media Group

Sanjaya, W. (2015). Perencanaan dan desain sistem pembelajaran. Kencana Prenada Media Group

Siregar, N.R. (2017). Persepsi siswa pada pelajaran matematika: studi pendahuluan pada siswa yang menyenangi game. Prosiding Temu Ilmiah X Ikatan Psikologi Perkembangan Indonesia, 1, 224-232

Trianto. (2014). Mendesain model pembelajaran inovatif, progresif, dan kontekstual. Prenadamedia Group 